\title{
marketing.
}

ČLANCI/PaPERS

\section{Elderly consumers existent or not? Portrayal of Consumers 65+ in Print Ads in Serbia}

Galjina Ognjanov

\begin{abstract}
The paper aims at opening a discussion on representation of elderly consumers in advertising messages in local markets. It builds upon previous studies in the US and Western Europe, tackling the issues of advertising addressed to elderly consumers. Theoretical background is rooted in socio-psychological theories of aging and advertising. In the empirical part, findings obtained from content analysis of 154 print ads portraying 280 models from different demographic cohorts are presented and discussed. The data indicate under-representation of ads featuring models over the age of 65 , however drawing attention to new products and services offered to elderly consumers in Serbia. In consequence, we may conclude that the elderly market in Serbia has not been limited only to health care products and supplements, but they have also been offered financial services (bank loans) and telecommunications services (internet) through specially created advertising messages addressing retired population. In addition, where existent in advertising creative elderly models are mostly centrally presented with no difference between female and male models $65+$.
\end{abstract}

Keywords: Elderly consumers, Advertising, Print media, Exploratory study, Content analysis

\section{INTRODUCTION}

Substantial attention in advertising research has recently been paid to changes driven by proliferation of new media and the new communications patterns wholeheartedly accepted by consumers belonging to young generational cohorts X, Y, Z (eg. Wiedmer, 2015; Wenyu, Wang and Zhou 2006). These generational cohorts have also been considered the biggest and most important markets, therefore attracting almost exclusive attention in both academic research and advertising practice.

However, one should not neglect current demographic trends indicating the aging population phenomenon which is, according to the United Nations report for 2013, taking place in nearly all countries of the world. At the moment, it mostly concerns developed market economies, particularly those in Western Europe, yet none the less it also concerns the emerging market economies in Central, Eastern and Southern Europe. While in Western Europe the population 65+ accounts for $19.2 \%$, in Southern Europe it makes $18.8 \%$ of total population. Hence Serbia seems to be an adequate representative Southern Europe with elderly population (65+) accounting for $18.25 \%$ of overall population at the moment, and projected to grow to $23.44 \%$ as of 2026 (Statistical Office of the Republic of Serbia).

Though scattered attention has been paid to elderly consumers in recent studies published in international journals (eg. Carrigan, Szmigin, 2000; Chevalier, Lichtlé, 2012; Barnhart, Peñaloza, 2013), the topic is not a brand new. In the fields of marketing and advertising, research interest in this topic goes back to the eighties of the last century (eg. Stivens, 1981; Smith, Moschis, Moore, 1985; Swayne, Greco, 1987; Nelson, Smith, 1988; Rahtz, Sirgy, Meadow, 1989). Prior to that, pioneering articles bringing to light the issues of ageing and its influence on changing social roles and behavior were published in journals in the fields of sociology and gerontology (eg. Blau, 1956; Blutena, Powers, 1978). Most of the articles however, addressed elderly consumers in the US, with limited attention paid to this issue in European studies.

Against such a backdrop, the paper aims at opening a discussion on elderly market in European countries, by paying special attention to advertising messages based on the use of models $65+$. The study presented here makes just a preliminary step in further research to better understand processing of advertising messages as well as measure its effectiveness 
with regards to affects, cognitions and behavior of elderly consumers. After providing a brief theoretical background, the paper focuses on findings obtained in an empirical study conducted in Serbia, and continues with deriving conclusions and implications for advertisers and further research.

\section{THEORETICAL BACKGROUND}

The study builds upon previous research studies tackling the issues of advertising addressed to elderly consumers. It is rooted in sociological and psychological theories of aging and applied in the theory of advertising. Sociological theory offers explanations on media consumption of the elderly founded in the disengagement and activity theories. Both theories serve to explain how elderliness is linked with the isolation from the society. In consequence, mass media are seen as a window open to the surrounding world and the most effective way for combating isolation (Smith, Moschis, Moore, 1985). Further, in accordance with social breakdown theory, elderly are given the role of a passive audience, thus potentially being highly influenced by mass media (Rahtz, Sirgy, Meadow, 1989).

On the other hand, psychological theory related with elderly is mostly concerned with deterioration of their cognitive processes, including the speed of processing messages and deterioration of memory, resulting in lower recall and recognition of advertising messages. While processing capacities are undoubtedly deteriorating by aging, it has been well accepted in theory that when messages are self-paced (i.e. processed without external constraint such as broadcasting time), message recall is less affected. Therefore, Montgomery, Taylor and Mitchell (1988), suggest that messages appealing to elderly should better be placed in print than broadcasting media.

The sociological and psychological theories of aging have been applied in advertising theory over the last few decades, in which substantial attention has been paid to the use of models and their influence on cognitions, affects and behavior of targeted consumers. Some recent studies find ageism still highly present in advertising, as older models are either non-existent in mainstream advertising, or they are depicted in inappropriate and stereotypical ways (Carrigan, Szmigin, 2000). Barnhart and Peñaloza (2013) claim that marketing scholars have contributed to construction of elderly as a marginalized and devalued subject position, finding the argument in conceptualization of later stages of family life cycle concept as Empty Nest or Solitary Survivors.
According to Chevalier and Lichtlé (2012) purchases made by senior consumers account for more than half the sales of new cars, mineral water, jam, etc. and even a third of children's toys. Yet, reported findings from research studies focusing on portrayal of elderly in print media in UK, Canada and US show that the elderly models are mostly under-represented in comparison to their share in total population. At the same time, while not generally negatively portrayed, they are frequently featured debilitated, and featured in ads promoting medical care products and general disability aids (Carrigan, Szmigin, 2000).

\section{EMPIRICAL STUDY}

\subsection{Methodology}

The study presented here is exploratory and based on content analysis of print advertisements. The research objective was to analyze portrayal of elderly consumers in advertising messages in Serbia. Previous research being inexistent, this study starts from very beginnings - with a preliminary research question being:

RQ1: At what extent are elderly models represented in print advertising messages in Serbia?

Provided an adequate representation of elderly models is found, further considerations would be related with:

RQ2: How are elderly models portrayed in advertisements?

RQ3: What are the main product/services offered to elderly consumers through the use of elderly models in advertising messages?

Like in previous studies (eg. Swayne, Greco, 1987; Greco, 1993) the elderly consumers were defined as consumers of the age of 65 and over, this being the legal age when the most of employees would be retired. In accordance with previously discussed sociological theory the act of retirement triggers radical changes in their social roles and behavior. On the other hand, it is also important to note that retired people in Serbia make an important market at present. Namely, due to high unemployment rate, particularly among young population, retired parents are now in a position to support their children and grandchildren.

Print ads for content analysis were collected over 30 consecutive days (March $15^{\text {th }}-$ April 15 $5^{\text {th }}, 2016$ ) in two dailies with the highest circulation in Serbia. Full colour ads of all sizes were included, while classified as well as those related with fundraising campaigns and political campaigns were excluded. In total, 661 
ad were collected. Models of various ages were found in 154 ads. Only models representing an ordinary person (i.e. a non-known actor) were eligible for the study. Well-known actors, celebrities, journalists and TV speakers and experts providing testimonials were excluded, as their credibility might not have been based only on their age but also on other characteristics.

Following similar study methodology applied by Swayne and Greco (1987), repeating ads were included in the analysis, for at least two reasons: 1 . the coder would anyway need to look repeatedly to a message before being able to analyze it, and 2. it resembles reality in a proper way, since in reality the consumers are exposed to repeated advertising messages.

The study was based on adjusted qualitative content analysis, with the primary goal to assess representation of elderly models in advertising. Therefore, it didn't exactly follow the strict guidelines in which a structured instrument is to be developed and independent coders are engaged. The ads were classified by the main researcher in several categories: a) those representing elderly models (age 65+), b) showing kids and teenagers, c) showing young models (20-30) and younger adults (31-40), d) showing mid age and senior population (41-65). However, to reduce the potential bias, 2 independent coders were asked to do separate classification on their own. As was expected, all the ads perceived as representing elderly consumers $(65+)$ were selected as such by the two independent coders, whereas differences among them appeared with regards to other demographic groups (which was out of scope of this paper).

To be classified in category $65+$, the following subjective criteria developed by Swayne and Greco (1987) were applied: appearance of retirement, extensive grey hair and wrinkles of the skin around the eyes and/or hands, use of ambulatory aids such as canes or wheelchairs, parent of a son or daughter who was middle-aged or older, and evidence of grandchildren or great-grandchildren.

Portrayal of models was assessed by analyzing elderly models position and role in ad creative. Due to rather small number of ads and small number of elderly models, these were coded by the main researcher. The same was applied in listing the products and services offered to elderly consumers.

\subsection{Findings}

The number of models presented in an ad ranged from 1 to 6 . A few ads showed elderly models in a family setting, with their children or grandchildren. Typically, those ads included 4 to 5 models, with 1 or 2 models belonging to demographic cohort $65+$. On the other hand, ads featuring only models $65+$ typically included only 1 to 2 persons. Table 1 . shows number of models presented in print ads.

\section{TABLE 1: Models presented in print advertisements}

\begin{tabular}{|l|c|c|}
\hline & $\begin{array}{c}\text { ALL } \\
\text { MODELS }\end{array}$ & $\begin{array}{c}\text { MODELS } \\
\text { 65+ }\end{array}$ \\
\hline Number of ads featuring models & 154 & 22 \\
\hline Number of models & 280 & 33 \\
Male & 110 & 19 \\
\hline Female & 170 & 14 \\
\hline
\end{tabular}

The above table clearly shows that the number of ads with elderly models is quite small (22), with only 33 models over the age of 65 . Moreover, as the duplication of messages included in the study was not controlled, it should be noted that among those 22 ads there were only 9 different creative solutions provided by only 8 different advertisers (four commercial banks, two pharmaceutical companies, one mobile telecommunications company and one retailer).

The position of elderly models in analyzed ads was assessed in comparison with other models representing younger demographic cohorts. Provided that they were all represented in a social setting (i.e. family gathering, attending social events, walking in nature etc), elderly models' position was assessed as background (only younger models were featured in the forefront), central (elderly models were featured in forefront together with younger models) and prominent (only elderly models were featured in forefront). With only two exceptions (one background and one prominent position), all other creative solutions featured central positions of elderly models.

The roles in which elderly models were presented in creative solutions included the following: family members (father/grandfather, mother/grandmother), emotional partners, retired persons, buyers, consumers, and even one student (creative solution for a bank loan for retired people featured an elderly woman in prominent position in an amphitheater together with young students and listening to a lecture).

The products/services advertised by featuring elderly models included the following: dietary supplements (11), bank loans and other financial services (7), mobile internet (2) and special discounts and payment benefits for retired people offered by retailers (2). 


\subsection{Discussion}

The findings obtained from content analysis clearly show under-representation of elderly consumers in print advertisements in Serbia. Namely, the number of ads featuring models $65+$ accounts for $14.28 \%$, and the number of models $65+$ represented in print ads accounts for only $11.78 \%$ of models of all ages featured in print ads. Comparing this with demographic structure of Serbian population (18.25\% of population $65+$ in $2014 ; 19.31 \%$ projected in 2016 , Statistical Office of the Republic of Serbia) elderly consumers seem to be under-represented in advertising messages. However, should these existed it would be interesting to compare the findings with similar ones from previous years. That would certainly lead to better understanding of changes in the approach of local advertisers with regards to elderly market. Alternatively, the study could be repeated in future to find out if the advertisers will adjust to the fact that the elderly market is growing.

With regards to elderly models represented in print ads, our attention might focus on the representation of male and female models of the age 65+. Opposite from what was found in the case of all modes, where female models (60.72\%) dominate the male (39.28\%), it is the male models $65+$ who were featured in majority cases whenever elderly models were included in advertising creative (i.e. 19 male and 14 female). Obviously, it is far from the real demographic situation in which elderly women account for higher percentage (20.51\% in 2014), than elderly man (15.86\% in 2014). In addition, it is also not typical for the real market situation in which women have more important role regarding household purchases. On the other hand, the market reality seems to be more adequately represented in the case of all models $(60.72 \%$ of all models were female, compared with $51.3 \%$ of female population in Serbia). While there seems to be no specific explanation for such a finding, this could be due to extremely small sample and therefore remains to be examined on bigger samples in future.

Yet another interesting finding is related with products and services offered to elderly market based on featuring models $65+$ in creative messages. As expected, among all advertised products/services dietary supplements are dominating ( $50 \%$ of all ads featuring elderly models), however there is also a substantial percentage of those offering bank loans and financial services (33\%). The latter realistically reflects current economic situation in Serbia, where retired people are supporting their younger family members. This fact makes them more interesting as potential clients to commercial banks. In addition, retailers have started to advertise more directly to retired persons, offering them special discounts for retired as well as possibility to pay in monthly installments over the period of 12 months. Finally, two ads (9\%) offered internet services, indicating that a company providing telecommunications services has found this market up and coming in near future.

\subsection{Study limitations}

Being exploratory in nature, the study faces the main limitations of all studies of this kind, allowing only few absolute conclusions (Sadoski, 1983). In that sense, one may only claim that elderly models in print ads in Serbia have not been completely inexistent, but the advertising creatives are still rather rarely based on their use. This also reflects from the next important limitation of the study, which is related with extremely small number of ads and elderly models, based on which the content analysis has been performed.

Yet another limitation comes from the fact that an adjusted qualitative content analysis was performed, meaning that neither structured instrument was applied nor independent coders were engaged. Therefore, it should also be noted that ad creatives were assessed rather subjectively by the main researcher, though certain steps have been undertaken in order to achieve better objectivity of the study. However, the two coders engaged to double check the main researcher's assessment were young enough so it should be noted that they might have perceived the age of elderly models differently (older than if the coders were more representative for elderly population). Still, the former limitation was controlled to certain point, as the ads included in the sample typically showed gray haired people, grandmothers and grandfathers, or the models were explicitly named as retired persons, while in several cases even their age was explicitly noted down by advertisers.

\subsection{Conclusions and implications}

Based on the presented findings, one could judge upon latent exclusion of elderly consumers in Serbia. However, the elderly market is not completely neglected by local advertisers, whereas due to changing social and economic conditions it might be expected to gain in importance in the years to come.

In general, with the exception of noticed under-representation of elderly, their portrayal in adver- 
tising seems to be positive and nonstereotyped. Elderly models are featured centrally, occupying socially and economically important roles - family members, partners, consumers and buyers. Contrary to ones expectations based on findings reported in similar studies abroad, they have not been offered only health care and supplements, but they have also been offered financial services (bank loans) and telecommunications services (internet).

Regarding the implications of presented findings for advertising practice one should mention the fact that print ads still make an important communications channel for elderly population. While younger generational cohorts are moving toward online channels, elderly are still loyal to traditional print, therefore making the most critical mass of readers of daily papers. In addition, print ads are processed at self-controlled pace, which gives them an important advantage over TV ads, particularly in the case of elderly (due to age related deterioration of their cognitive functions). In consequence, advertisers should strongly consider the strategy of placing their ads in print media with a subsequent use of elderly models, while shaping their ads to better communicate with elderly consumers.

On the other hand, further research should be directed at better understanding of how use of elderly models may influence elderly consumers, with regards to their cognitions, affects and behavior. Moreover, elderly population should be further fragmented into smaller age categories (eg. 65-74, over 75, and especially over 85 ) as there must be significant differences in their cognitive capacities and consumer behavior.

\section{Literature}

1. Blau, Z. S. (1956). Changes in Status and Age Identification. American Sociological Review, 21(April), 198-203.

2. Barnhart, M., \& Peñaloza, L. (2013). Who Are You Calling Old? Negotiating Old Age Identity in the Elderly Consumption Ensemble. Journal of Consumer Research, 39(6), 1133-1153.

3. Bultena, G.L. \& Powers, E.A. (1978). Denial of Aging: Age Identification and Reference Group. Journal of Gerontology, 33 (October), 748-754.

4. Carrigan, M. \& Szmigin, I. (2000). Advertising and older consumers: image and ageism. Business Ethics: A European Review, 9(1), 42-50.

5. Chevalier, C. \& Lichtlé, M.C. (2012). The Influence of the Perceived Age of the Model Shown in an Ad on the Effectiveness of Advertising. Recherche et Applications en Marketing (English Edition) (AFM c/o ESCP-EAP), 27 (2), 3-19.

6. Greco, A. J. (1993). The Incidence and Portrayal of the Elderly in Television Advertising. Journal of Marketing Theory and Practice, 2(1), 140-155.

7. Montgomery, R.D., Taylor, R.D. \& Mitchell, M.A. (1988), The Impact of Retirement, Occupation, and Activity of the Cognitive Processes of the Elderly. Journal of Marketing Management 8(2), 52-65

8. Nelson, S.L. \& Smith, R.B. (1988). The Influence of Model Age or Older Consumers' Reactions to Print Advertising. Current Issues \& Research in Advertising, 11(1), 189-213.

9. Rahtz, D.R., Sirgy, M. J., \& Meadow, H.L. (1989). The Elderly Audience: Correlates of Television Orientation. Journal of Advertising, 18(3), 9-20.
10. Sadoski, M.(1983). An Exploratory Study of the Relationships between Reported Imagery and the Comprehension and Recall of a Story. Reading Research Quarterly, 19(1), 110-123

11. Smith, R.B., Moschis, G.P. \& Moore, R. L (1985). Some Advertising Influences on the Elderly Consumer: Implications for Theoretical Consideration. Current Issues \& Research in Advertising, 8(2), 187-202.

12. Statistical Office of the Republic of Serbia data base, available at: http://webrzs.stat.gov.rs/WebSite/public/ ReportView.aspx

13. Stephens, N. (1981). Media Use and Media Attitude Changes with Age and with Time. Journal of Advertising, 10(1), 38-47.

14. Swayne, L.E., \& Alan J. Greco. (1987). The Portrayal of Older Americans in Television Commercials. Journal of Advertising, 16(1), 47-54.

15. Wiedmer, T. (2015). Generations Do Differ: Best Practices in Leading Traditionalists, Boomers, and Generations X, Y, and Z. Delta Kappa Gamma Bulletin, 82(1), 51-58.

16. Wenyu D., Wang, G. \& Nan Zhou (2006). Generational and Regional Differences in Media Consumption Patterns of Chinese Generation X Consumers, Journal of Advertising, 35(2), 101-110

17. World population aging, United Nations, 2013, available at: http://www.un.org/en/development/ desa/population/publications/pdf/ageing/ WorldPopulationAgeing2013.pdf 


\section{marketing}

\section{Apstrakt:}

\section{Zastupljenost starijih potrošača u štampanim oglasima u Srbiji}

Galjina Ognjanov

Osnovni cilj rada je iniciranje diskusije o zastupljenosti starijih potrošača u oglasnim porukama u Srbiji. Specifičan cilj je da se ukaže na njihovo relativno malo prisustvo u kreativnim rešenjima lokalnih agencija, što u poređenju s njihovom zastupljenošću kao potrošača na srpskom tržištu ukazuje na svojevrsno marketinško slepilo na strani ponude, ali i otvara pitanje diskriminacije jedne starosne kohorte. Istraživanje čiji su rezultati prikazani u radu zasniva se na saznanjima opisanim u brojnim studijama o potrošačima starijim od 65 godna i njihovoj zastupljenosti u oglasnim porukama sprovedenim u SAD i Zapadnoj Evropi. Teorijski okvir istraživanja čine socio- psihološke teorije starenja, kao i teorija oglašavanja. Empirijski deo bavi se analizom 154 štampane oglsane poruke u kojima se pojavljuje 280 promotera („modela“), pripadnika različitih starosnih kohorti. Podaci prikupljeni u istraživanju ukazuju na izrazito malu zastupljenost oglasa u kojima su prikazani modeli stariji od 65 godina. Ipak, uočava se i to da se u oglasima u kojima se ovi modeli pojavljuju nude sasvim različiti proizvodi, među kojima su i neki malo očekivani s obzirom na iskustvo ostalih zemalja u kojima su sprovedena slična istraživanja.

Ključne reči: Stariji potrošači, Oglašavanje, Štampani mediji, Analiza sadržaja

Napomena: Rad je prezentovan na naučnoj konferenciji „Izazovi i problemi savremenog marketinga“ održanoj na Zlatiboru od 17. do 19. novembra 2017. godine i publikovan u zborniku radova čiji je izdavač časopis Marketing.

Kontakt:

Galjina Ognjanov, galja@ekof.bg.ac.rs 